\title{
Origin Myth in Austronesian Language Speaking Tribes of Southeast Asia
}

\author{
By Cooper Peltz
}

Spanning from the mid $-19^{\text {th }}$ century to the beginning of the $20^{\text {th }}$ century, travelogue writers spun tales of Malayan and Dutch East Indian tribal savagery. These patrons of colonialism perceived the tribes' traditional stories as grotesque and uncivilized mythologies. One such myth was the story of the creation of man. The travelogue writers recounted story after story told by each tribe of how man came to be on the planet. One can see thematic similarities between the different tribal accounts of creation; however, many of the travelogue writers failed to recognize the similarities of the accounts. What stories did the Austronesian language speaking tribes of colonial British Malay, the Dutch East Indies and the Spanish Philippines tell regarding the origin of man, and what did the travelogue writers think of these stories? I argue that the common themes between Malay language Southeast Asian creation myths of man-from-earth and man-from-tree developed from the 6,000-year evolution of the language. The travelogue writers were puzzled by where the myths had originated and deemed the myths abnormal.

The travelogues give the reader a rich cultural history of Southeast Asia not found in other texts; however, the information in the travelogues is limited by the writers' cultural bias. The bias is due to an incomplete understanding of Southeast Asian culture and language. The designation "Austronesian Language" is an umbrella term. Though this term seems simple, it actually includes the languages of tribes located eleven thousand miles apart. With the complexities of all of these languages, one would have a difficult time relaying an unbiased account of the Austronesian language speaking tribes' mythologies. As a researcher, one can transcend the inherently biased accounts of events written in the travelogues by acknowledging that the reports are biased. Additionally, one can study the bias in the documents to learn about the author 
and his or her culture.

Though this paper is a study based on colonial travelogues form the $18^{\text {th }}$ century, European nations began to colonize the rest of the world by the end of the $15^{\text {th }}$ century. The Portuguese, Spanish, French, English, and Dutch were the major colonial powers. The Americas, Africa, and Asia all felt the European presence by the mid- $16^{\text {th }}$ century. The quick spread of colonialism was due in part to the stagnant European economy and intense political competition during the $15^{\text {th }}$ and $16^{\text {th }}$ century. European imperialism was founded on the credence that non-European races were inferior to Europeans. Therefore, exploitation of other continents' people and resources was deemed acceptable. This theory of hegemony compelled the European nations to impose colonialism on Asian nations. A way for Europeans to reconcile their relationship with the East is now called "Orientalism." Orientalism is the basic belief that there is a clear difference between the Western world and the Eastern world. ${ }^{1}$ To take ownership of their colonies, colonial powers renamed places in the colonies. The new names were meant to forcibly assimilate the new colony into the European empire. ${ }^{2}$

European colonialism was not the first time Southeast Asia underwent colonization. ${ }^{3}$ However, European colonization may have been more coercive than earlier attempts at colonization. The type of coercion European colonizers used is called, "Anti-Conquest." Anti-conquest is achieved by maintaining the façade of magnanimity while seizing control of another country. For European colonization of Southeast Asia, the anti-conquest was under the guise of civilizing barbarous Southeast Asia. For compensation, imperialists exploited Southeast Asian natural resources and laborers. Another justification for the subjugation of Southeast Asia was to spread Christianity to the region. ${ }^{5}$ Starting around 1850, European powers applied more political authority on the Southeast Asian colonies. This development in relations shaped regional

1 Edward W. Said, Orientalism (New York: Vintage Books, 1978), 2.

2 HAN Mui Ling, "From Travelogues to Guidebooks: Imagining Colonial Singapore, 1819-1940," Sojourn 18, no. 2 (2003): 267.

3 Nicholas Tarling, A Concise History of Southeast Asia (New York: Frederick A. Praeger, Publishers, 1966), 26.

4 Mary Louise Pratt, Imperial Eyes: Travel Writing and Transculturation (London: Routledge, 1992), 9.

5 Taufik Abdullah, “Asia and European Colonialism,” Asia Europe Journalism 1, no.1 (2003): 68. 
events for over a century. ${ }^{6}$ Outright colonialism ended after World War II, though colonial effects can still be seen today.

\section{Origin of Man}

Colonists recorded the origin myths of tribes in the Malay Peninsula and the Philippines. The tribal myths colonists wrote about contained similar motifs among each other. The first common theme in Austronesian language speaking tribal mythology is that man was created out of the Earth. The Mantras of the Malay Peninsula believed that the first magician and his brother were made out of "Handful of Earth" and "Drop of Water," mother and father, respectively. The first magician learned how to propagate man on the Earth from the Lord of the Underworld. ${ }^{7}$ To the predominantly Christian colonists the mention of the "Lord of the Underworld" brings forth visions of a red man with a pitchfork. But to this Malayan tribe, the Lord of the Underworld simply ruled over the land where their ancestors resided. Furthermore, this story did not have the religious connotations the Europeans put onto it. The underworld to the colonists represented something entirely different from the underworld of this story.

The Dyaks of British Sakarran had a similar man-from-earth myth. Dyak is the generic name for all tribes living in Borneo. ${ }^{8}$ The Sakarran were made out to be villainous pirates and headhunters until the White Rajah, Sir James Brooke, took control of the tribe's land. The Dyaks were prosperous under Brooke's government. As a result of the widespread prosperity, tribal chiefs supported Brooke's regime. ${ }^{9}$ The Dyaks explained man's origin in this way: the Supreme Being created two birds. The birds created man out of earth after trees and rocks were decided to be poor creative material. In the Dyaks' story, man was not created by God, but by birds God had created. To the colonists

6 John Bastin and Harry J. Benda, A History of Modern Southeast Asia: Colonialism, Nationalism, and Decolonization (Englewood Cliffs: Prentice-Hall, Inc., 1968), 34.

7 Walter William Skeat, Pagan Races of the Malay Peninsula, 2 (Ithaca: Cornell University

Press, 1906), 336.

8 Mrs. McDougall, Letters from Sarawak; Addressed to a Child: Embracing an Account of the Manners, Customs, and Religion of the Inhabitants of Borneo; The Progress of the Church Mission, and Incidents of Missionary Life Among the Natives (London: Grant and Griffith, 1854), 68.

9 Frederick Boyle, Adventures among the Dyaks of Borneo (London: Hurst and Blackett, Publishers, 1865), 171. 
this notion of indirect creation flies in the face of Christianity, where man was directly created by God and is God's chosen caretaker of the Earth; however, in the view of this tribe from Borneo, man is simply part of nature and not its overlord.

The third example of a man-from-earth myth came from a tribe on the Lundu River in Southwest Sarawak. The river Lundu is home to many Sea Dyaks, Chinese immigrants and Malays. The tribes of the area were welcoming of all ethnicities except the Sibuyas. ${ }^{10}$ The tribe's creation story was thus: God, Battara, created man. With dirt in his left hand he made woman and with the dirt in his right hand came man. The story was probably taken from the Malays, and it was the common story told by the neighboring tribes. ${ }^{11}$

The second motif of Austronesian language speaking tribal creation myths is that man was created from trees. The Kayan people of central Sarawak sang their creation story in a rhymed blank verse. The first two humans were born from the union of a large tree on the Earth and a creeper from the moon. These two humans, a male and female respectively, were incomplete. They did not have their lower half, so their entrails hung out the bottom. These two incomplete beings produce the first complete beings. ${ }^{12}$ This creation myth also has a similarity with the creation myth of the Dyaks of Sakarran. In both stories, a process of events resulted in the creation of man. The process was a trial and error process in the Sakarran myth, and the process was one of incompletion to completion in the Kayan myth.

A second man-from-tree myth was collected from the Visayan tribe of the Philippines. In this story, a vulture hovered over the Earth. He dove down to Earth and split a bamboo shoot. Out of this bamboo shoot came a man and

10 Spenser St. John, Life in the Forests of the Far East; or Travels in Northern Borneo (London: Smith, Elder and Co., 1863), 27.

11 Rodney Mundy, Narrative of Events in Borneo and Celebes, Down to The Occupation of Labuan: From the Journals of James Brooke, ESQ., Rajah of Sarawak, and Governor of Lebaun, 1 (London: John Murray, 1848), 295.

12 Charles Hose and William McDougal, The Pagan Tribes of Borneo: A Description of their Physical Moral and Intellectual Condition with some Discussion of their Ethnic Relations, 2 (New York: The MacMillan Company, 1912), 138. 
a woman. ${ }^{13}$ The Visayan myth has an aspect in common with the Sakarran myth as well. Both myths use birds as the active agent in the creation of man.

\section{Origin of Myth}

Travelogue writers attempted to deduce the origin of the tribal myths they recounted. The colonists' theories were widely based on conjecture. Colonists believed that Austronesian language tribal myths were influenced by an unknown, outside source. Myths of the Malay Peninsula were categorized into two sections. The stories were either from a foreign source or from Indonesia itself. ${ }^{14}$ Anthropologically speaking, the outside source described by the travelogue writers is 6,000 years of cultural development within Austronesian language speaking Southeast Asian communities. Pre-colonialism, the Malay Peninsula was ruled by multiple sultanates. The sultanates formed three distinct principalities after Britain began applying more control over the area in the mid-19th century. ${ }^{15}$ These sultanates most likely had contact with the tribes of the backwaters of the peninsula. Sultanate contact could have been the outside source that led to cultural exchange including an exchange of myths.

The common Austronesian linguistic ancestry provides a clue as to where the myths originated. The Austronesian language spread over Southeast Asia around 6,000 years ago. The spread of the language was due to a large-scale emigration from China. The Austronesian-speaking people spread from southern China to Taiwan and diffused throughout the Southeast Asian islands thereafter. ${ }^{16}$ Therefore, myths of the Austronesian language speaking tribes of Southeast Asia could have their origin in China.

Common linguistic ancestry created a way for different myths to coalesce. The subgroup of Austronesian language spoken in Borneo, the Malay Peninsula

13 Fedor Jagor, "Jagor's Travels in the Philippines," in The Former Philippines Thru Foreign Eyes, edited by Austin Craig (New York: D. Appleton and Company, 1917), 285.

14 R.J. Wilkinson, "Malay Literature," in Twentieth Century Impressions of British Malaya: Its History, People, Commerce, Industries, and Resources, edited by Arnold Wright (London: Lloyd's Greater Britain Publishing Company, LTD., 1908), 230.

15 Abdul Razak Baginda, "Remembering and Forgetting: Directions for Malaysia's Future," in Memory and History in East and Southeast Asia, edited by Gerrit W. Gong (Washington, D.C.: The CSIS Press, 2001), 136. 16 John Edward Terrell, "Introduction: 'Austronesian' and the Great Austronesian Migration," World Archeology 36, no. 4 (2004): 587. 
and the Philippines is Western Malayo-Polynesian. ${ }^{17}$ Western Malayo-Polynesian language speaking tribes settled in Borneo, specifically, thousands of years ago. More settlers arrived in Borneo sometime after the initial settling. These new groups contributed to the original settlers both culturally and linguistically. These two distinct waves of settlers had assimilated into one by the time of European colonialism. ${ }^{18}$ Because of the common linguistic ancestry the multiple waves could successfully combine into one general culture. The general culture, however, had many subsets in the form of each specific tribe.

A parallel example of linguistic ancestry is seen in the evolution of Austroasiatic languages. On a slightly different branch of the linguistic family tree, Austroasiatic languages of Southeast Asia have been similarly studied. The Austroasiatic language is also spoken in the South Asian subcontinent. ${ }^{19}$ The Austroasiatic myths vary per tribe. The myth variation is attributed to influences from neighboring civilizations. Other variations are attributed to environmental, social, and economic development of each group. Some myths explain why some tribes live in the mountains and others live near the ocean. When the myth is carried from one geographical location to another, it changes over time to suit the environment. ${ }^{20}$ The theory of changing stories to suit environment can be applied to Austronesian language as well.

Though current anthropologists can trace the progression of myth through language throughout Southeast Asia, travelogue writers of the colonial period could only provide conjecture as to the origin of the tribal myths. One author purported that all Orientals are superstitious, but the "savage" tribes of Borneo have especially fanciful myths. ${ }^{21}$ The travelogue writer did not see the traceable lines from one tribe's myths to another tribe's myths. The author's inability to see the lines of descent could be aided by a racist view of "Orientals."

17 Ross Clark, "Austronesian Languages," in The World's Major Languages, edited by Bernard Comrie (New York: Oxford University Press, 1987), 904.

18 Bernard Sellato and Peter Sercombe, "Borneo, Hunter-Gatherers, and Change," in Beyond the Green Myth: Borneo's Hunter-Gatherers in the Twenty-First Century, edited by Peter Sercombe and Bernard Sellato (Denmark: NIAS Press, 2007), 6.

19 Sanford B. Steever, "Tamil and the Dravidian Languages," in The World's Major Language, edited by Bernard Comrie (New York: Oxford University Press, 1987), 725.

20 Dang Nghiem Van, "The Flood Myth and the Origin of Ethnic Groups in Southeast Asia," The Journal of American Folklore 106, no. 421 (1993): 304.

21 Philip C. Coote, The Malay States (London: A. \& C. Black, LTD., 1923), 32. 
Other writers perceived the commonalities between Southeast Asian myths. The people of Malay would take an idea from a European legend and work their own story to communicate the same idea. Thus, the Malay people created a new story with the same moral. Malay myth had influences from Arabian and Persian legends, Indian epics, and Javanese stories. ${ }^{22}$ The similarities between outside cultures' myths and Malay myths led the travelogue writers to believe the Malay's stole indiscriminately from all cultures. Though the Malays did not steal from all cultures, they may have been in the practice of the reinterpretation and re-imagination of old Austronesian stories to make them new. The author saw that the tribal myths have influences, but he did not locate the correct birthplace of the myths.

An alternate argument for why similar motifs pop up in Austronesian tribal creation myths can be explained through mythology theory. Myth, itself, is supposed to be read synchronously. That is, multiple myths about the same subject are supposed to be read together. Though the stories are repetitive, they are not identical. Each story is meant to show another instance of overcoming a problem in a slightly different way. Because the premise is the same but the stories can change, there can be an infinite number of stories that attack the same premise. The justification for the repetitive nature of myth explains why there are so many myths that have to do with the creation of man in Southeast Asia. The tribes were simply attacking the question of how man came to be. The answer to this question came in the form of many slightly different myths. The synchronal theory is an alternative model to colonial missionary, Dr. Mason's Universal Revelation theory. ${ }^{23}$ In similar form, the Israelites who wrote the book of Genesis came to the same questions the tribes of Southeast Asia did. Both peoples asked, "How did we get here?" The different tribes wrote different stories trying to answer the same premise. ${ }^{24}$

Myth theorist, Joseph Campbell, has written a plethora of books on my-

22 R.J. Wilkinson, "Malay Literature," in Twentieth Century Impressions of British Malaya: Its History, People, Commerce, Industries, and Resources, edited by Arnold Wright (London: Lloyd's Greater Britain Publishing Company, LTD., 1908), 229.

23 Albert Fytche, Burma Past and Present with Personal Reminiscences of the Country, 1 (London: C. Kegan Paul \& Co., 1878), 166.

24 Claude Levi-Strauss, "The Structural Study of Myth," in Myth: A Symposium, edited by Thomas A. Sebeok (Bloomington: Indiana University Press, 1958), 105. 
thology; however, his books show his research through the lens of a western worldview. He identifies the Jungian collective unconscious, and not ancestral linguistics, as the cause of the similar motifs in mythology. Furthermore, Campbell argues that myth is defined as religious in nature, having to do with cosmological and ontological insights. He relegates stories dealing with immediate history to the category of legends. ${ }^{25}$ However, Campbell's definitions have an overt European cultural bias. In Austronesian language speaking tribes of Southeast Asia, stories of the origin of man are devoid of religiosity, but they still deal with cosmological and ontological quandaries. ${ }^{26}$ Campbell's claims of universal Jungian myth structure are shown to be untrue when tested against the differing uses of myth in different world cultures. ${ }^{27}$ Though the arguments set forth by Campbell are convincing, he argues from a Western standpoint. To be taken seriously, the theorist must argue from the specific Southeast Asian point of view.

\section{Connotations of Myth}

Travelogue writers' views of the tribal myths were skewed by their western bias. Thus, the authors could not understand the function of tribal myth. Many Austronesian language tribal creation stories can be compared to the Biblical account of the creation of man, but they are not meant for the same effect. Most European Colonizers saw the tribal myths as barbaric and irreligious, however some of the myths did have the Biblical creation story's structure. The travelogue writers looked upon the myths that were close to Biblical text unfavorably, without realizing the similarities.

Borneo had many myths that deal with the origin of man, but they were not associated with religious teachings as in European thought. The stories did not provoke the listener to be changed after hearing the story, like the stories of the Bible. The stories were purely for literary effect and not for religious or

25 Joseph Campbell, The Flight of the Wild Gander: Explorations in the Mythological Dimension (New York: The Viking Press, 1969), 16.

26 Charles Hose and William McDougal, The Pagan Tribes of Borneo: A Description of their Physical Moral and Intellectual Condition with some Discussion of their Ethnic Relations, 2 (New York: The MacMillan Company, 1912),138.

27 Robert A. Segal, "Joseph Campbell's Theory of Myth," in Sacred Narrative: Reading in the Theory of Myth, edited by Alan Dundes (Berkeley: University of California Press, 1984), 256. 
scientific effect. ${ }^{28}$ The colonizers could not comprehend this divorce of origin story and religion. What Europeans held as sacred was not the same as what the tribes from Borneo held sacred.

A parallel study of irreligious myth is found in northern Philippines. The Ifugao tribe of northern Philippines performs the Alim. The Alim is a ritualistic chant. The subject matter of the Alim can range from folk songs to mythology. The chant is only known to a few tribe members and is never performed for fun. Though the ritualism suggests that the Alim is part of a religion, it is not. ${ }^{29}$ This ritual is an example of the divorce of ritualistic storytelling and religion. Another parallel study of irreligious myth is of the Huaulu tribe. The Huaulu tribe of Seram has an exclusive recitation called the aitetukiniem. These narrative stories are sacred, but they are not religious. If the raconteur fumbles the story, it may cost him his life. The storytellers are the old men of the village. Old age is believed to put one in closer contact with the ancestors, and thus more in touch with the myth..$^{30}$ The aitetukiniem has a spiritual aspect, but it is not tied to religion. To an average colonial European, spirituality and religion were one in the same. Confronted with an alternative structure of spirituality, the colonists labeled the tribes as savages.

Myth is meant to put one's body and mind in sync. Myth keeps the mind in line with the body and the body in line with nature. ${ }^{31}$ One can see the alignment of mind, body and nature in how the Austronesian language speaking tribes of Southeast Asia coexisted with nature. Since man was created from nature, man should respect nature as they do their mother. The tribes' coexistence with nature can be contrasted with what transpired in Europe during the same time period: the Industrial Revolution. Europeans were plundering the Earth of its resources. The Europeans subjugated the Earth where the tribes coexisted with the Earth. Europeans and Southeast Asian tribes per-

28 Charles Hose and William McDougal, The Pagan Tribes of Borneo: A Description of their Physical Moral and Intellectual Condition with some Discussion of their Ethnic Relations, 2 (New York: The MacMillan Company, 1912),138.

29 Rosario Bona de Santos, “The Ifugao Alim: Chanted Narrated Dramatic Discourse in Ritual," Humanities Diliman 10, no. 1 (2013): 2.

30 Valerio Valeri, The Forest of Taboos: Morality, Hunting, and Identity Among the Huaulu of the Moluccas (Madison: University of Wisconsin Press, 2000), 192.

31 Joseph Campbell, The Power of Myth (New York: Doubleday, 1988), 70. 
formed diametrically opposite actions. The opposing actions can be traced to the two cultures' mythology. In European mythology, man was the overlord of the Earth. In tribal mythology, man was the child of the Earth.

Missionaries attempted to inject religion into the myths of the Southeast Asian tribes. In Burma, missionaries Dr. and Mrs. Mason "worked hard to civilize" the Karens. The Karens were an ethnic group dispersed throughout Burma. Dr. Mason translated the Karen origin stories from, "Rude verses." The origin of man myths and traditions can be found in many ancient nations. Dr. Mason says that the source of these legends had to have come from a written source, and the only source could be the Old Testament. He deduces that they must have gotten these stories from Chinese Jews who had access to the Pentateuch, before the Karens emigrated from China. The author does not judge the stories of the Karens as quickly as Dr. Mason and allows for another explanation: A "Universal Revelation," which was given before the Jews' "Special Revelation," may have started the stories before the writing of the Old Testament. ${ }^{32}$

\section{European Travelogue Writers' Reaction}

Along with recounting the tribal myths of Southeast Asia, the writers added their own analysis of the myths. The travelogue writers harbored contesting opinions about tribal creation myths. The tribal myths were widely regarded as uncultured; however, some writers argued the tribal myths had validity. The An Amok tribe was estimated to be the, "Lowest savages in the scale." This assessment was given after listening to their mythology. ${ }^{33}$ Another author supplies his own mythology of the origin of man in Java. His myth masquerades as a scientific line of reasoning. He postulates that the aborigines did not have the brain function to develop the arts of divination and astrology until after contact with outside cultures. Before the clash of cultures their minds were primitive and, "Not much superior," to animals with no culture. ${ }^{34}$ However,

32 Albert Fytche, Burma Past and Present with Personal Reminiscences of the Country,1 (London: C. Kegan Paul \& Co., 1878), 166.

33 J.F. McNair, Perak and the Malays (Kuala Lumpur: Oxford University Press, 1972), 219.

34 Donald MacLaine Campbell, Java: Past E Present: A Description of the Most Beautiful Country in the World, Its Ancient History, People, Antiquities, and Products, 1 (London: William Heinemann, 1915), 12. 
since the publication of the racist travelogue, anthropologists have discovered that Java had complex social structure, multiple variants of language, and hierarchical religious systems hundreds of years before coming into contact with other peoples. ${ }^{35}$

Conversely, some travelogue writers showed some understanding with a patronizing magnanimity. One author called the Malaccan tribe Sun-gie-ujong a rude nation; however, the author also said that their myths told "more or less" of what he called truth. He asserted that the stories should not be devalued because there was no historical evidence to refute what the tribesmen said. ${ }^{36}$

Furthermore, another writer criticizes humanity's inability to explain something novel without comparing it to something the reader was familiar with. In travel writing an author said the sea was as blue as the Mediterranean and the reader had a frame of reference for the place the author was describing. Describing something relatively necessarily establishes the object the speaker was describing as unusual, rather than the normality the listener had experienced. This unusualness was many times deemed as strange, threatening, or uncivilized. Though the tribal expression of an idea was different, the idea itself was the same. The theory that one idea can have multiple expressions can be applied to the creation-of-man myth. While Europeans had a canonized story of how man was created that was different from the tribes of Southeast Asia, it did not mean that the Europeans and tribesmen were not aspiring to answer the same question. The man that created the myth saw the proliferation of his species and decided to find a way to explain how they came to exist. $^{37}$

Austronesian language speaking tribes in Southeast Asia had many myths discussing the origin of man. Two clear motifs can be seen in the origin myths. The first motif is man-from-earth, and the second motif is man-from-tree. The similarities in motifs can be explained through the evolution of the Austronesian language.

35 M.C. Ricklefs, War, Culture and Economy in Java: 1677-1726 (Sydney: Allen \& Unwin, 1993), 4.

36 T.J. Newbold, Political and Statistical Account of the British Settlements in the Straits of Malacca, 2 (London: John Murray, 1839), 106.

37 Frank Athelstane Swettenham, ed., Unaddressed Letters (London: The Bodley Head, 1898), 259. 
Travelogue writers of the colonial period wrote down the origin myths, including their own biases. Some travelogue writers saw these myths as savage, while other writers did not judge the stories so harshly. 


\section{BIBLIOGRAPHY}

Abdullah, Taufik. "Asia and European Colonialism.” Asia Europe Journalism 1, no.1 (2003): 61-74.

Baeten, Elizabeth M. The Magic Mirror: Myth's Abiding Power. Albany: State University of New York Press, 1996.

Baginda, Abdul Razak. "Remembering and Forgetting: Directions for Malaysia's Future." In Memory and History in East and Southeast Asia, edited by Gerrit W. Gong, 134-146. Washington, D.C.: The CSIS Press, 2001.

Bastin, John and Harry J. Benda. A History of Modern Southeast Asia: Colonialism, Nationalism, and Decolonization. Englewood Cliffs: Prentice-Hall, Inc., 1968.

Boyle, Frederick. Adventures among the Dyaks of Borneo. London: Hurst and Blackett, Publishers, 1865.

Brocheux, Pierre and Daniel Hemery. Indochina: An Ambiguous Colonization: 18581954. Berkeley: University of California Press, 2009.

Campbell, Donald MacLaine. Java: Past E Present: A Description of the Most Beautiful Country in the World, Its Ancient History, People, Antiquities, and Products, 1. London: William Heinemann, 1915.

Campbell, Joseph. The Flight of the Wild Gander: Explorations in the Mythological Dimension. New York: The Viking Press, 1969.

Campbell, Joseph. The Power of Myth. New York: Doubleday, 1988.

Clark, Ross. “Austronesian Languages.” In The World's Major Languages, edited by Bernard Comrie, 901-911. New York: Oxford University Press, 1987.

Coote, Philip C. The Malay States. London: A. \& C. Black LTD., 1923.

De Santos, Rosario Bona. "The Ifugao Alim: Chanted Narrated Dramatic Discourse in Ritual." Humanities Diliman 10, no. 1 (2013): 1-43.

Endicott, Karen L. and Kirk M. Endicott. The Headman was a Woman: The Gender Egalitarian Batek of Malaysia. Long Grove: Waveland Press, Inc., 2008. 
Flytche, Albert. Burma Past and Present with Personal Reminiscences of the Country, 1. London: C. Kegan Paul \& Co., 1878.

Hose, Charles and William McDougal. The Pagan Tribes of Borneo: A Description of their Physical, Moral and Intellectual Condition with some Discussion of their Ethnic Relations, 2. New York: The MacMillan Company, 1912.

Jagor, Fedor. "Jagor's Travels in the Philippines." In The Former Philippines Thru Foreign Eyes, edited by Austin Craig, 285. New York: D. Appleton and Company, 1917.

Levi-Strauss, Claude. “The Structural Study of Myth.”In Myth: A Symposium, edited by Thomas A. Sebeok, 81-106. Bloomington: Indiana University Press, 1958.

Ling, HAN Mui. "From Travelogues to Guidebooks: Imagining Colonial Singapore, 1819-1940." Sojourn 18, no. 2 (2003): 257-278.

McDougall, Mrs. Letters from Sarawak; Addressed to a Child: Embracing an Account of the Manners, Customs, and Religion of the Inhabitants of Borneo; The Progress of the Church Mission, and Incidents of Missionary Life Among the Natives. London: Grant and Griffith, 1854.

McNair, J.F. Perak and the Malays. Kuala Lompur: Oxford University Press, 1972.

Mundy, Rodney. Narrative of Events in Borneo and Celebes, Down to The Occupation of Labuan: From the Journals of James Brooke, ESQ., Rajah of Sarawak, and Governor of Lebaun,1. London: John Murray, 1848.

Newbold, T.J. Political and Statistical Account of the British Settlements in the Straits of Malacca, vol. II. London: John Murray, 1839.

Osborne, Milton. Southeast Asia: An Introductory History. South Leonards: Allen \& Unwin, 1997.

Pratt, Mary Louise. Imperial Eyes: Travel Writing and Transculturation. London: Routledge, 1992. 
Ricklefs, M.C. War, Culture and Economy in Java: 1677-1726. Sydney: Allen \& Unwin, 1993.

Roth, Henry Ling. The Natives of Sarawak and British North Borneo: Based Chiefly on the MSS. Of the Late Hugh Brook Low Sarawak Government Service, 1. London: Trustlove \& Hanson, 1896.

Said, Edward W. Orientalism. New York: Vintage Books, 1978.

Segal, Robert A. "Joseph Campbell's Theory of Myth." In Sacred Narrative: Reading in the Theory of Myth, edited by Alan Dundes, 256-269. Berkeley: University of California Press, 1984.

Sellato, B. and P.G. Sercombe. "Borneo, Hunter-Gatherers, and Change." In Beyond the Green Myth: Borneo's Hunter-Gatherers in the Twenty-First Century, edited by Peter Sercombe and Bernard Sellato, Denmark: NIAS Press, 2007.

Skeat, Walter William. Pagan Races of the Malay Peninsula, 1. New York: The Mac Millan Company, 1906.

Skeat, Walter William. Pagan Races of the Malay Peninsula, 2. Ithaca: Cornell University Press, 1906.

St. John, Spenser. Life in the Forests of the Far East; or Travels in Northern Borneo. London: Smith, Elder and Co., 1863.

Swettenham, Frank Athelstane, ed. Unaddressed Letters. London: The Bodley Head, 1898.

Tarling, Nicholas. A Concise History of Southeast Asia. New York: Frederick A. Praeger, Publishers, 1966.

Terrell, John Edward. "Introduction: 'Austronesian' and the Great Austronesian Migration." World Archeology 36, no. 4 (2004): 586-590.

Valeri, Valerio. The Forest of Taboos: Morality, Hunting, and Identity Among the Huaulu of the Moluccas. Madison: University of Wisconsin Press, 2000. 
Van, Dang Nghiem. "The Flood Myth and the Origin of Ethnic Groups in Southeast Asia." The Journal of American Folklore 106, no. 421 (1993): 304-337.

Wilkinson, R.J. “Malay Literature." In Twentieth Century Impressions of British Malaya:

Its History, People, Commerce, Industries, and Resources, edited by Arnold Wright, 230. London: Lloyd's Greater Britain Publishing Company LTD., 1908. 